\title{
CHARACTERIZATION OF SOIL CHEMICAL PROPERTIES OF STRAWBERRY FIELDS USING PRINCIPAL COMPONENT ANALYSIS $^{(1)}$
}

\author{
Gláucia Oliveira Islabão ${ }^{(2)}$, Marília Alves Brito Pinto ${ }^{(2)}$, Lisiane Priscila Roldão Selau ${ }^{(3)}$, \\ Ledemar Carlos Vahl ${ }^{(4)}$ \& Luís Carlos Timm ${ }^{(5)}$
}

\begin{abstract}
SUMMARY
One of the largest strawberry-producing municipalities of Rio Grande do Sul (RS) is Turuçu, in the South of the State. The strawberry production system adopted by farmers is similar to that used in other regions in Brazil and in the world. The main difference is related to the soil management, which can change the soil chemical properties during the strawberry cycle. This study had the objective of assessing the spatial and temporal distribution of soil fertility parameters using principal component analysis (PCA). Soil sampling was based on topography, dividing the field in three thirds: upper, middle and lower. From each of these thirds, five soil samples were randomly collected in the $0-0.20 \mathrm{~m}$ layer, to form a composite sample for each third. Four samples were taken during the strawberry cycle and the following properties were determined: soil organic matter (OM), soil total nitrogen $(N)$, available phosphorus $(P)$ and potassium $(K)$, exchangeable calcium (Ca) and magnesium (Mg), soil $\mathbf{p H}(\mathrm{pH})$, cation exchange capacity (CEC) at $\mathrm{pH}$ 7.0, soil base (V\%) and soil aluminum saturation( $\mathrm{m} \%$ ). No spatial variation was observed for any of the studied soil fertility parameters in the strawberry fields and temporal variation was only detected for available $K$. Phosphorus and $K$ contents were always high or very high from the beginning of the strawberry cycle, while $\mathrm{pH}$ values ranged from very low to very high. Principal component analysis allowed the clustering of all strawberry fields based on variables related to soil acidity and organic matter content.
\end{abstract}

Index terms: Fragaria $x$ ananassa Duch, soil fertility, multivariate analysis, temporal variability.

\footnotetext{
(1) Part of Master degree thesis of the first author by the Post-Graduation Program in Agronomy, "Eliseu Maciel" Faculty of Agronomy, Federal University of Pelotas - PPGA/FAEM/UFPel Received for publication on March 28, 2012 and approved on November 29, 2012

(2) PhD, Student PPGA/UFPel. CEP 96001-970 Pelotas (RS). E-mail: gislabao@gmail.com; ma.agro@gmail.com

(3) Adjunct Professor, Statistics Departament, Federal University of Rio Grande do Sul - UFRGS. E-mail: lisianeselau@gmail.com

(4) Titular Professor, Department of Soil Science, EMCA/UFPel. E-mail: lcvahl@ufpel.edu.br

(5) Associate Professor, Departament of Rural Engineering, FAEM/UFPel. CNPq Scholarship. E-mail: lctimm@ufpel.edu.br
} 


\title{
RESUMO: CARACTERIZAÇÃO DE LAVOURAS DE MORANGO QUANTO AOS ATRIBUTOS QUÍMICOS DO SOLO COM O USO DA ANÁLISE DE COMPONENTES PRINCIPAIS
}

\begin{abstract}
Um dos locais que mais se produz morango no Estado do Rio Grande do Sul é o município de Turuçu. O sistema de produção de morango adotado pelos produtores desse município é similar aos sistemas adotados em outras regiões do Brasil e no mundo; entretanto, a principal diferença se encontra no manejo do solo utilizado, que pode alterar os seus atributos químicos durante o ciclo do morango. O objetivo deste trabalho foi avaliar a distribuição temporal e a espacial dos parâmetros de fertilidade do solo, usando a análise de componentes principais (PCA). Foram selecionadas 14 lavouras onde a amostragem de solo em cada uma foi com base na sua topografia, dividindo a área em três terços: superior, mediano e inferior. Em cada um desses terços, coletaram-se, de forma aleatória, cinco amostras simples de solo na camada de 0-0,20 m, formando uma amostra composta em cada terço. Foram realizadas quatro amostragens ao longo do ciclo da cultura do morango e determinados os seguintes atributos químicos: matéria orgânica $(M O)$, nitrogênio total $(N)$, fósforo $(P)$, potássio $(K)$, cálcio $(C a)$, magnésio (Mg), capacidade de troca de cátions (CTC) a pH 7,0, pH em água (pH), saturação por bases (V\%) e saturação por alumínio ( $m \%$ ). Os resultados evidenciaram que nenhum dos parâmetros de fertilidade do solo estudados apresentou variação espacial dentro das lavouras e apenas o K apresentou variação temporal. Os teores de P e de Kestiveram sempre altos ou muito altos desde o início do ciclo da cultura do morango, enquanto o $\mathrm{pH}$ variou de muito baixo até muito alto. A análise de componentes principais permitiu o agrupamento das lavouras de morango com base nas variáveis relacionadas à acidez do solo e matéria orgânica.
\end{abstract}

Termos de indexação: Fragaria x ananassa Duch, fertilidade do solo, análise multivariada, variabilidade temporal.

\section{INTRODUCTION}

The world production of strawberries is approximately 4.2 million tons per year, and the United States, Turkey, Spain, Korea, and Egypt are the leading producers (FAO, 2011). Currently the strawberry production in Brazil is 133,000 tons,mainly in the States of Minas Gerais, São Paulo and Rio Grande do Sul (Portal do Agronegócio, 2011). One of the main centers of strawberry production in Rio Grande do Sul is Turuçu, a county in the southern region of the State. The production and sale of fresh strawberries represent a significant source of revenues for producers, constituting a basis of income, employment generation and social inclusion and consequently of improvement in the quality of life on these farms.

The strawberry production system used in Turuçu (RS), is very similar to the systems of other strawberryproducing regions in Brazil and worldwide (Bamberg et al., 2011). Most producers grow the strawberry plants in beds under low polypropylene tunnels. According to personal information of technical staff of Emater in Turuçu, few producers use soil analyses to determine the levels of fertilizers and lime requirements according to the crop-specific recommendations. Cattle manure, turkey manure and mineral fertilizers are commonly used to fertilize the beds before planting the seedlings and fertigation is applied during the rest of the strawberry cycle. Based on data provided by a producer, it was estimated that an average 3.87, 5.84 and $6.84 \mathrm{~g} / \mathrm{plant}$ of $\mathrm{N}, \mathrm{P}$ and $\mathrm{K}$, respectively, are applied via organic and mineral fertilization before transplanting and fertigation after wards, aside from a variable mixture of $\mathrm{Ca}, \mathrm{Mg}, \mathrm{S}$, and micronutrients. Strawberry plants require 1.92, 0.36 and $2.40 \mathrm{~g} / \mathrm{plant}$ of $\mathrm{N}, \mathrm{P}$ and $\mathrm{K}$, respectively, (Castro et al., 2003; Tagliavini et al., 2005) to produce an amount of $1 \mathrm{~kg}$ of fruit (fresh weight) per plant. Despite the low use efficiency of nutrients from fertilizers by the plants, the applied rates exceed the crop requirement by far. Such high fertilizer rates can lead to the accumulation of soluble nutrients in the soil.

One of the statistical tools to study the changes in soil chemical properties is the principal component analysis (PCA), which is a multivariate technique of covariance structure modeling, where the basic idea is to find latent variables that represent linear combinations of a group of variables under study which are in turn related to each other (Ferreira, 2008).

The PCA has been used in several other agricultural studies, for example: Guedes et al. (2006) evaluated the chemical properties of soil and nutrition of eucalypt after applying biosolids to the soil; Mandal et al. (2008) assessed the effect of the quality of irrigation water on different soil chemical, physical and biological properties; Valladares et al. (2008) studied the behavior of 19 soil profiles with high levels of organic material from different regions of Brazil; Carvalho Júnior et al. (2008) investigated the main 
differences between physical and chemical properties of Ultisol salong the Atlantic coastline of Brazil; Nyiraneza et al. (2009) studied variations in corn yieldin relationto soil properties; and Adhikari et al. (2011) applied PCA to determine physical and chemical properties of soils irrigated with wastewater.

The objective of this study was to evaluate the temporal and spatial distribution of soil fertility parameters throughout the strawberry cycle in the county of Turuçu (RS), and group them for similarities by principal component analysis (PCA).

\section{MATERIAL AND METHODS}

\section{Description of the study area}

For this study, we selected 14 strawberry fields of producers of the Association of Strawberry Farmers of Turuçu, located in the South of the State of Rio Grande do Sul (Figure 1).

The county of Turuçu is located in the transition between the geomorphological units Shield and Coastal plain of Rio Grande do Sul (Tagliani, 2002). Ultisols, Inceptisols and Aqualfs (Soil Survey Staff, 2006) are the three main soil types found in this region.

The climate of the region was classified as Cfa (Köppen).The mean annual temperature is around $17.8{ }^{\circ} \mathrm{C}$, with warmest mean in January $\left(23.2^{\circ} \mathrm{C}\right)$ and coldest in July $\left(12.3^{\circ} \mathrm{C}\right)$. In the region, there is a slight variation of average monthly precipitation with a regular distribution over all months, with highest rainfall $(153.3 \mathrm{~mm})$ in February and lowest in
November (99.5 mm) and March (97.4 mm) (Estrela, 2008).

The strawberry production system in Turuçu is characterized by the planting of seedlings from temperate regions (Chile and Argentina), on small areas $(<1 \mathrm{ha})$ cultivated by family labor. To prepare the beds, the soil is previously plowed with a tractordrawn rotary hoe and then covered with black plastic mulch. The seedlings are transplanted into beds (width 0.8-1.0 m, height $0.2 \mathrm{~m}$ ), in 2-3 rows spaced $0.3 \mathrm{~m}$ apart.Water and nutrients (mainly $\mathrm{N}, \mathrm{P}, \mathrm{K}$, and $\mathrm{Ca}$ nutrients) are applied by a drip irrigation system during the crop cycle.

\section{Soil sampling}

Soil sampling in each strawberry field was based on the topography, dividing the area in three thirds, according to the slope: an upper, middle and lower third. From each of these thirds, five samples were randomly collected with a simple Dutch auger from the $0-0.20 \mathrm{~m}$ layer, to form a composite sample representing each third. Each field was sampled four times throughout the strawberry cycle; the $1^{\text {st }}$ sampling (S1) occurred when the strawberry seedlings were transplanted to the beds (May 2007), the $2^{\text {nd }}$ (S2) when farmers initiated irrigation (August 2007), the $3^{\text {rd }}$ (S3) at harvest (November 2007) and the $4^{\text {th }}$ sampling (S4) after the harvest and the end of irrigation (February 2008).

\section{Soil chemical analysis}

The following soil chemical properties were studied: organic matter $(\mathrm{OM})$, total nitrogen $(\mathrm{N})$, phosphorus $(\mathrm{P})$, potassium $(\mathrm{K})$, calcium $(\mathrm{Ca})$, magnesium $(\mathrm{Mg})$,

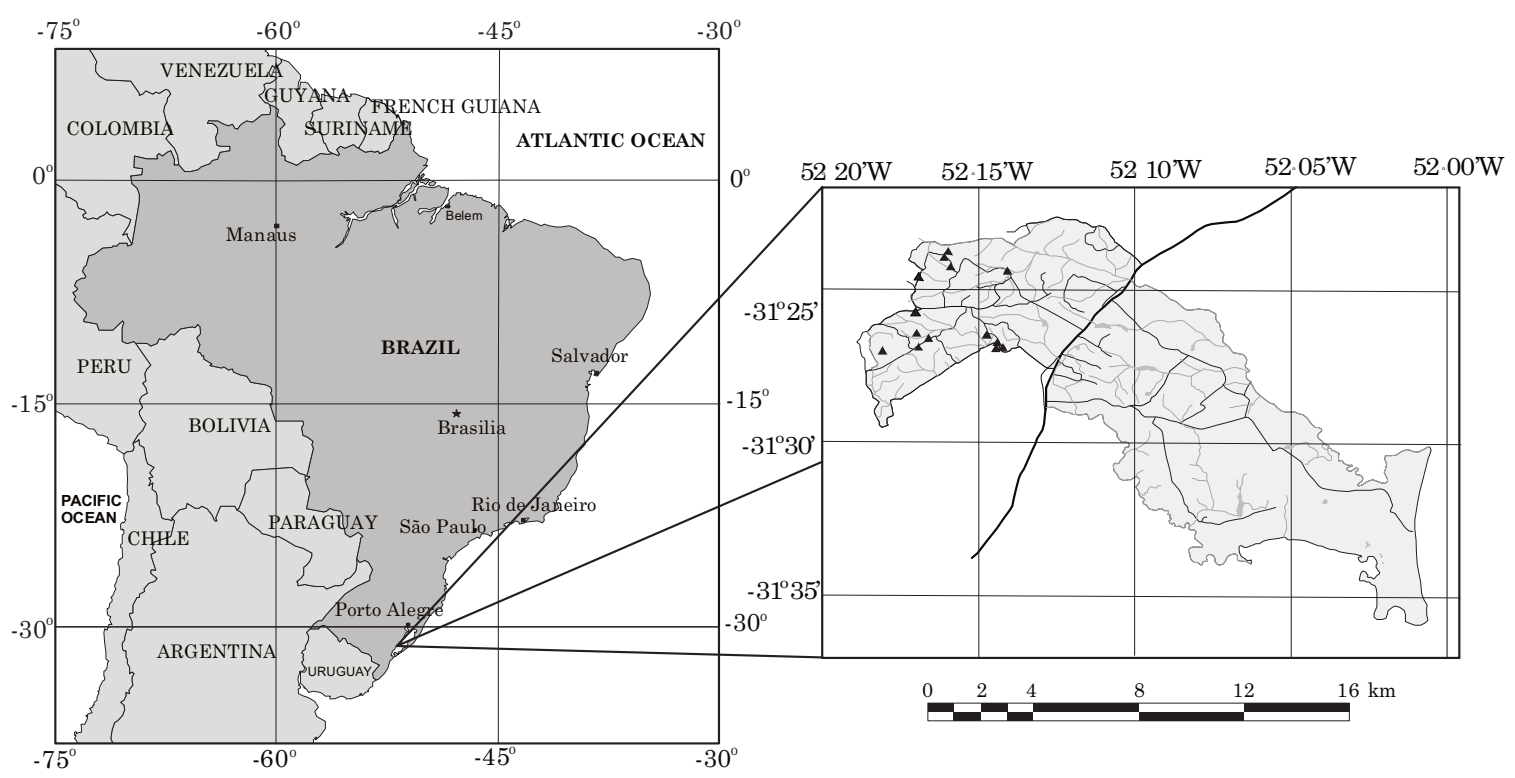

Figure 1. Location of the 14 strawberry fields under study in the county of Turuçu (RS). Adapted from Bamberg et al. (2011). 
cation exchange capacity (CEC) at $\mathrm{pH} 7.0, \mathrm{pH}$ in water $(\mathrm{pH})$, base-saturation percentage $(\mathrm{V} \%)$ and $\mathrm{Al}-$ saturation percentage $(\mathrm{m} \%)$. Chemical analyses were performed according to the methods described by Tedesco et al. (1995): $\mathrm{pH}$ measurement in water at a 1:1 soil/water ratio, extraction of exchangeable $\mathrm{Ca}$ and $\mathrm{Mg}$ with $1 \mathrm{~mol} \mathrm{~L}^{-1} \mathrm{KCl}$ and determination by atomic absorption spectrophotometry. Available P and K were estimated by Mehlich-1, analyzing $\mathrm{K}$ by flame photometry and $\mathrm{P}$ by colorimetry; extraction of exchangeable $\mathrm{Al}$ with $1 \mathrm{~mol} \mathrm{~L}^{-1} \mathrm{KCl}$ and titration analysis with $0.0125 \mathrm{~mol} \mathrm{~L}^{-1} \mathrm{NaOH}$; and organic carbon was determined by the Walkley-Black combustion method. For OM, the data of organic carbon were multiplied by 1.724 . Based on the results of chemical analyses, the CEC, V\% and $\mathrm{m} \%$ were calculated.

\section{Data analysis}

Descriptive analysis of all data sets was performed by classical statistics, determining the minimum and maximum values and calculating the values of mean, median, coefficient of variation, coefficient of skewness and kurtosis. The hypothesis of data normality was verified by the KolmogorovSmirnov test (K-S).

To determine the effects of sampling location (upper, middle and lower third) and of sampling time on the soil chemical variables, the technique of repeated measure analysis was applied, using the SAS Proc Mixed procedure. To group the related soil chemical properties and thus explain most of the variance with a small set of new variables, we applied the principal component analysis (PCA), based on the correlation matrix between the components and standardized variables. All analyses were performed using the statistical software package Statistical Analysis System (SAS, 1985).

\section{RESULTS AND DISCUSSION}

\section{Descriptive statistics}

The statistical measures of position (mean and median values) and of dispersion (coefficient of variation - CV), the coefficients of skewness and kurtosis and the Kolmogorov-Smirnov (K-S) test of the data sets of OM, N, P, K, Ca , Mg, CEC, pH, $\mathrm{m} \%$, and V\% at four sampling times (S1, S2, S3 and S4) are presented in table 1 . The data dispersion of $\mathrm{N}, \mathrm{P}, \mathrm{Ca}, \mathrm{Mg}$, and $\mathrm{m} \%$ around the mean value was high $(\mathrm{CV}>35 \%)$ in all samplings throughout the strawberry cycle, according to the Wilding \& Drees (1983) classification. The OM data dispersion in S1, S2 and S3 was also high as well the dispersion of $\mathrm{K}$ data in $\mathrm{S} 1, \mathrm{~S} 2$ and $\mathrm{S} 4$ and of CEC pH 7.0 data in S2. The degree of dispersion of the distribution of V\% in all samplings, of OM in S4, of K in S3 and of CEC at all four samplings was moderate $(15 \%<\mathrm{CV}<35 \%)$.
The dispersion of the variable $\mathrm{pH}$ was low $(\mathrm{CV}<15 \%)$ in all samples. The high dispersion for most data sets can be explained by the scope of the study area and the segmentation of the fields in upper, middle and lower thirds.

According to the recommendations of the soil fertility commission CQFSRS/SC (2004), the P levels were very high ( $\left.>42.0 \mathrm{mg} \mathrm{dm}^{-3}\right)$ in all strawberry fields, while $\mathrm{K}$ contents were high in $62.5 \%$ of the fields $\left(61-120 \mathrm{mg} \mathrm{dm}^{-3}\right)$ and very high in $37.5 \%$ (> $\left.120 \mathrm{mg} \mathrm{dm}^{-3}\right)$. In a study investigating a commercial strawberry field, Araújo (2011) also found very high $\mathrm{P}$ and $\mathrm{K}$ levels, and even after the end of the experiment, the levels of these nutrients in the soil remained high and virtually unchanged in relation to the soil analysis prior to the experiment.

Although the average $\mathrm{pH}$ remained stable during the strawberry cycle (samplings) at around 5.5, the highest values tended to increase with time (Table 1). This increase may be related to the fertigation with very high nitrate concentrations in relation to the ammonia concentrations, which can increase the $\mathrm{pH}$ value due to high level of anions in relation to cations (Marschner, 1995). Values of $\mathrm{pH}$ of around 4.2 are detrimental to the development of strawberry due to $\mathrm{Al}$ toxicity ( $\mathrm{m}$ of $32-44 \%$ ), whereas values of $\mathrm{pH}>7$ can cause deficiencies of micronutrients such as $\mathrm{Mn}$, $\mathrm{Fe}, \mathrm{Cu}$, and $\mathrm{Zn}$. According to Kaminski et al. (2007), in soils of $\mathrm{pH}<5.5, \mathrm{Al}^{3+}$ is toxic to crops, with the first symptom being root growth inhibition. The same authors explained that, as a result, the water and nutrient uptake is impaired, since the presence of $\mathrm{Al}$ disrupts the cell plasma membrane of the root tissue, affecting its stiffness and permeability, hampering or invalidating the selectivity of nutrient absorption mechanisms. The $\mathrm{pH}$ in water considered suitable for strawberry plants ranges from 5.0-6.0 (Santos et al., 2005). Thus, although the average $\mathrm{pH}$ of the fields is adequate, the $\mathrm{pH}$ in some fields was limiting for being very low and limiting in others for being very high, due to excessive liming.

The skewness of most data distributions was positive and the highest values of the skewness coefficients were for the $\mathrm{K}$ data in $\mathrm{S} 1, \mathrm{~S} 2$ and $\mathrm{S} 4$ and $\mathrm{Mg}$ in S3 (Table 1). Visconti et al. (2009), studying soil saturation extracts in Spain, also found higher positive skewness for the variable $\mathrm{K}$ and attributed this to the fact that fertilizers may have been applied at a higher concentration at some locations. Negative skewness was observed for the V\% data at all sampling times and for $\mathrm{pH}$ and $\mathrm{K}$ data at sampling time $\mathrm{S} 3$. By the K-S statistical measure at $1 \%$ probability, it was found that only the data of $\mathrm{m} \%$ in S1, S3 and S4 have non-normal distribution.

\section{Repeated Measure Analysis}

The effects of soil sampling locations (thirds) and sampling times on the studied soil chemical properties 
Table 1. Soil chemical variables of strawberry fields at four sampling times

\begin{tabular}{|c|c|c|c|c|c|c|c|c|}
\hline Variable & Minimum & Maximum & Mean & Median & CV (\%) & Skewness & Curtosis & K-S \\
\hline & \multicolumn{8}{|c|}{ 1st sampling } \\
\hline $\mathrm{OM}\left(\mathrm{g} \mathrm{kg}^{-1}\right)$ & 6.88 & 32.68 & 16.58 & 15.16 & 40.86 & 0.67 & -0.36 & $0.14^{\mathrm{N}}$ \\
\hline $\mathrm{N}\left(\mathrm{g} \mathrm{kg}^{-1}\right)$ & 0.31 & 1.44 & 0.73 & 0.66 & 38.30 & 0.85 & -0.09 & $0.16^{\mathrm{N}}$ \\
\hline $\mathrm{P}\left(\mathrm{mg} \mathrm{dm} \mathrm{m}^{-3}\right)$ & 13.17 & 282.08 & 126.91 & 115.46 & 51.81 & 0.63 & -0.21 & $0.14^{\mathrm{N}}$ \\
\hline $\mathrm{K}^{+}\left(\mathrm{cmol}_{\mathrm{c}} \mathrm{dm}^{-3}\right)$ & 0.24 & 1.54 & 0.52 & 0.40 & 60.63 & 2.00 & 3.65 & $0.18^{\mathrm{N}}$ \\
\hline $\mathrm{Ca}^{2+}\left(\mathrm{cmol}_{\mathrm{c}} \mathrm{dm}^{-3}\right)$ & 0.84 & 7.57 & 3.26 & 3.20 & 49.49 & 0.78 & 0.48 & $0.09^{\mathrm{N}}$ \\
\hline $\mathrm{Mg}^{2+}\left(\mathrm{cmol}_{\mathrm{c}} \mathrm{dm}^{-3}\right)$ & 0.17 & 3.67 & 1.08 & 0.99 & 63.57 & 1.73 & 4.57 & $0.09^{\mathrm{N}}$ \\
\hline $\operatorname{CEC}\left(\mathrm{cmol}_{\mathrm{c}} \mathrm{dm}^{-3}\right)$ & 3.63 & 13.75 & 7.17 & 6.64 & 33.97 & 1.04 & 0.76 & $0.16^{\mathrm{N}}$ \\
\hline $\mathrm{pH}$ & 4.53 & 6.57 & 5.50 & 5.54 & 10.77 & 0.10 & -1.15 & $0.10^{\mathrm{N}}$ \\
\hline $\mathrm{m}(\%)$ & 1.21 & 35.25 & 8.31 & 3.55 & 111.47 & 1.64 & 1.70 & $0.28^{\mathrm{NN}}$ \\
\hline \multirow[t]{2}{*}{$\mathrm{V}(\%)$} & 30.85 & 90.52 & 66.65 & 72.51 & 23.98 & -0.79 & -0.57 & $0.16^{\mathrm{N}}$ \\
\hline & \multicolumn{8}{|c|}{ 2nd sampling } \\
\hline $\mathrm{OM}\left(\mathrm{g} \mathrm{kg}^{-1}\right)$ & 8.96 & 32.55 & 16.04 & 14.61 & 39.46 & 1.09 & 0.41 & $0.18^{\mathrm{N}}$ \\
\hline $\mathrm{N}\left(\mathrm{g} \mathrm{kg}^{-1}\right)$ & 0.04 & 1.77 & 0.7 & 0.61 & 44.57 & 1.29 & 2.69 & $0.15^{\mathrm{N}}$ \\
\hline$P\left(m g d m^{-3}\right)$ & 36.12 & 232.05 & 134.08 & 124.95 & 38.89 & 0.16 & -0.74 & $0.09^{\mathrm{N}}$ \\
\hline $\mathrm{K}^{+}\left(\mathrm{cmol}_{\mathrm{c}} \mathrm{dm}^{-3}\right)$ & 0.14 & 0.92 & 0.32 & 0.28 & 39.44 & 2.53 & 8.49 & $0.25^{\mathrm{N}}$ \\
\hline $\mathrm{Ca}^{2+}\left(\mathrm{cmol}_{\mathrm{c}} \mathrm{dm}^{-3}\right)$ & 0.90 & 7.64 & 3.01 & 2.72 & 52.06 & 0.99 & 0.90 & $0.12^{\mathrm{N}}$ \\
\hline $\mathrm{Mg}^{2+}\left(\mathrm{cmol}_{\mathrm{c}} \mathrm{dm}^{-3}\right)$ & 0.14 & 4.39 & 1.09 & 0.91 & 83.52 & 1.96 & 4.97 & $0.14^{\mathrm{N}}$ \\
\hline CEC $\left(\mathrm{cmol}_{\mathrm{c}} \mathrm{dm}^{-3}\right)$ & 2.59 & 13.39 & 6.77 & 6.15 & 35.11 & 0.85 & 0.69 & $0.11^{\mathrm{N}}$ \\
\hline $\mathrm{pH}$ & 4.19 & 6.92 & 5.40 & 5.40 & 12.99 & 0.30 & -0.70 & $0.08^{\mathrm{N}}$ \\
\hline $\mathrm{m}(\%)$ & 0.00 & 43.81 & 8.65 & 2.70 & 128.04 & 1.53 & 1.46 & $0.23^{\mathrm{N}}$ \\
\hline \multirow[t]{2}{*}{$\mathrm{V}(\%)$} & 25.38 & 89.60 & 63.81 & 68.30 & 26.46 & -0.62 & -0.73 & $0.13^{\mathrm{N}}$ \\
\hline & \multicolumn{8}{|c|}{ 3rd sampling } \\
\hline $\mathrm{OM}\left(\mathrm{g} \mathrm{kg}^{-1}\right)$ & 8.18 & 32.36 & 16.45 & 14.65 & 38.44 & 0.96 & 0.22 & $0.16^{\mathrm{N}}$ \\
\hline $\mathrm{N}\left(\mathrm{g} \mathrm{kg}^{-1}\right)$ & 0.13 & 1.53 & 0.70 & 0.61 & 44.05 & 0.92 & 1.09 & $0.15^{\mathrm{N}}$ \\
\hline$P\left(\mathrm{mg} \mathrm{dm}^{-3}\right)$ & 55.68 & 306.85 & 150.45 & 145.73 & 36.18 & 0.55 & 0.29 & $0.06^{\mathrm{N}}$ \\
\hline $\mathrm{K}^{+}\left(\mathrm{cmol}_{\mathrm{c}} \mathrm{dm}^{-3}\right)$ & 0.14 & 0.31 & 0.24 & 0.24 & 18.88 & -0.53 & -0.47 & $0.08^{\mathrm{N}}$ \\
\hline $\mathrm{Ca}^{2+}\left(\mathrm{cmol}_{\mathrm{c}} \mathrm{dm}^{-3}\right)$ & 0.78 & 6.61 & 2.95 & 2.69 & 50.78 & 0.91 & 0.33 & $0.13^{\mathrm{N}}$ \\
\hline $\mathrm{Mg}^{2+}\left(\mathrm{cmol}_{\mathrm{c}} \mathrm{dm}^{-3}\right)$ & 0.07 & 3.30 & 0.95 & 0.84 & 74.06 & 1.63 & 3.39 & $0.14^{\mathrm{N}}$ \\
\hline $\operatorname{CEC~}\left(\mathrm{cmol}_{\mathrm{c}} \mathrm{dm}^{-3}\right)$ & 3.44 & 12.28 & 6.55 & 6.15 & 32.57 & 1.02 & 0.64 & $0.12^{\mathrm{N}}$ \\
\hline $\mathrm{pH}$ & 4.18 & 7.38 & 5.56 & 5.84 & 15.16 & -0.05 & -0.95 & $0.13^{\mathrm{N}}$ \\
\hline $\mathrm{m}(\%)$ & 0.00 & 37.63 & 8.53 & 2.32 & 135.11 & 1.32 & 0.25 & $0.33^{\mathrm{NN}}$ \\
\hline \multirow[t]{2}{*}{$\mathrm{V}(\%)$} & 28.17 & 88.48 & 62.85 & 67.50 & 28.49 & -0.57 & -0.97 & $0.18^{\mathrm{N}}$ \\
\hline & \multicolumn{8}{|c|}{ 4th sampling } \\
\hline $\mathrm{OM}\left(\mathrm{g} \mathrm{kg}^{-1}\right)$ & 10.48 & 35.28 & 19.13 & 17.64 & 33.35 & 0.66 & -0.40 & $0.12^{\mathrm{N}}$ \\
\hline $\mathrm{N}\left(\mathrm{g} \mathrm{kg}^{-1}\right)$ & 0.32 & 1.42 & 0.68 & 0.57 & 38.91 & 0.78 & -0.18 & $0.18^{\mathrm{N}}$ \\
\hline$P\left(m g d m^{-3}\right)$ & 62.35 & 295.36 & 144.76 & 145.51 & 38.75 & 0.74 & 0.07 & $0.10^{\mathrm{N}}$ \\
\hline $\mathrm{K}^{+}\left(\mathrm{cmol}_{\mathrm{c}} \mathrm{dm}^{-3}\right)$ & 0.18 & 0.92 & 0.33 & 0.29 & 45.44 & 2.06 & 4.90 & $0.19^{\mathrm{N}}$ \\
\hline $\mathrm{Ca}^{2+}\left(\mathrm{cmol}_{\mathrm{c}} \mathrm{dm}^{-3}\right)$ & 0.88 & 8.24 & 3.39 & 3.19 & 46.37 & 0.89 & 1.05 & $0.08^{\mathrm{N}}$ \\
\hline $\mathrm{Mg}^{2+}\left(\mathrm{cmol}_{\mathrm{c}} \mathrm{dm}^{-3}\right)$ & 0.11 & 4.57 & 1.13 & 0.93 & 78.59 & 1.69 & 4.46 & $0.10^{\mathrm{N}}$ \\
\hline $\operatorname{CEC}\left(\mathrm{cmol}_{\mathrm{c}} \mathrm{dm}^{-3}\right)$ & 3.98 & 14.38 & 7.25 & 6.67 & 32.73 & 0.99 & 0.84 & $0.11^{\mathrm{N}}$ \\
\hline $\mathrm{pH}$ & 4.34 & 7.20 & 5.47 & 5.58 & 14.20 & 0.10 & -0.89 & $0.15^{\mathrm{N}}$ \\
\hline $\mathrm{m}(\%)$ & 0.70 & 32.12 & 7.08 & 1.98 & 132.15 & 1.54 & 1.05 & $0.30^{\mathrm{NN}}$ \\
\hline $\mathrm{V}(\%)$ & 33.54 & 92.13 & 66.56 & 74.59 & 24.43 & -0.54 & -1.02 & $0.19^{\mathrm{N}}$ \\
\hline
\end{tabular}

OM: organic matter; $\mathrm{m}(\%)$ : Al saturation; V(\%): base saturation; CV (\%): coefficient of variation; K-S: Kolmogorov-Smirnov statistical value, where $\mathrm{N}$ : normal at $1 \%$ and $\mathrm{NN}$ : non-normal. 
throughout the strawberry cycle were evaluated by means of multivariate analysis of repeated measures (Table 2).

There was no effect of the sampling locations (third) in the field on the studied soil chemical properties since the $\mathrm{Pr}>\mathrm{F}$-values were greater than $1 \%$ (Table 2). This indicates that the field topography did not influence the spatial distribution of the soil chemical properties, indicating that there was no displacement of nutrients from higher to lower elevations, which could increase the concentrations of elements in the middle and lower thirds.

The different sampling times were used to determine the effect of crop management by each producer on the studied soil chemical properties. However, the only significant effect of sampling time was observed for the $\mathrm{K}$ values (value of $\mathrm{Pr}>\mathrm{F}$ less than $1 \%$ ) (Table 2). This could be explained by the fact that in spite of the constant fertigation throughout the strawberry cycle, $\mathrm{K}$ plant uptake was higher than the K applied to the soil until S3. On the other hand, $\mathrm{K}$ uptake by strawberry plants decreased at the end of the cycle (between S3 and S4) and the $\mathrm{K}$ content in the soil increased. Domínguez et al. (2009) observed significant seasonal variation in K levels in strawberry leaves during the cycle, although the values declined gradually, reaching a minimum at the end of the production cycle.

The levels of the other nutrients that were also applied via fertigation varied little over time, since their application-uptake relation was constant throughout the strawberry cycle. According to Carvalho (2006), as the strawberry cycle is long, it is recommended to split the total fertilizer amount to reduce nutrient losses and maintain soil fertility continuously close to optimum at each stage of plant growth, thus reducing leaching losses. There was no effect of the interaction third versus sampling time on the soil chemical properties (Table 2).

\section{Principal Component Analysis}

Since the K values differed significantly throughout the sampling period (Table 2), the values of the residues were used for the PCA. For the other variables, the original values were used in the PCA. The principal component analysis considered the first two factors, which had an accumulated eigenvalue of $73.6 \%$ (Table 3 ). The first and second principal components are a result of the linear combination of the 10 studied variables and both explained $51.7 \%$ and $21.9 \%$ of the variance, respectively.

The first component was negatively correlated with the variable $\mathrm{m} \%$ and positively with the other variables (Figure 2). Thus, the effect of the variation factor of the variable $\mathrm{m} \%$ led to a reduction of its values while the values of other variables increased. This component can be interpreted as a response related to the soil acidity and to liming. The relationship with

Table 3. Eigenvalue and accumulated proportion of principal component analysis

\begin{tabular}{cccc}
\hline Component & Eigenvalue & Proportion & $\begin{array}{c}\text { Accumulated } \\
\text { proportion }\end{array}$ \\
\hline 1 & 5.170 & 0.517 & 0.517 \\
2 & 2.192 & 0.219 & 0.736 \\
3 & 1.049 & 0.105 & 0.841 \\
4 & 0.742 & 0.074 & 0.915 \\
5 & 0.340 & 0.034 & 0.949 \\
6 & 0.248 & 0.025 & 0.974 \\
7 & 0.113 & 0.011 & 0.985 \\
8 & 0.086 & 0.009 & 0.994 \\
9 & 0.041 & 0.004 & 0.998 \\
10 & 0.017 & 0.002 & 1.000 \\
\hline
\end{tabular}

Table 2. Effects of soil sampling location (thirds) and sampling time on the studied soil chemical properties throughout the strawberry cycle, evaluated by means of repeated measures

\begin{tabular}{|c|c|c|c|c|c|c|}
\hline \multirow{2}{*}{ Variable } & \multicolumn{2}{|c|}{ Third } & \multicolumn{2}{|c|}{ Sampling } & \multicolumn{2}{|c|}{ Third versus sampling } \\
\hline & F value & $\operatorname{Pr}>\mathbf{F}$ & F value & $\operatorname{Pr}>\mathbf{F}$ & F value & Pr $>$ F \\
\hline MO $\left(\mathrm{g} \mathrm{kg}^{-1}\right)$ & 0.95 & 0.40 & 1.48 & 0.23 & 0.51 & 0.80 \\
\hline $\mathrm{N}\left(\mathrm{g} \mathrm{kg}^{-1}\right)$ & 0.34 & 0.72 & 0.17 & 0.92 & 0.55 & 0.77 \\
\hline $\mathrm{P}\left(\mathrm{mg} \mathrm{dm}^{-3}\right)$ & 1.36 & 0.27 & 0.83 & 0.49 & 0.20 & 0.98 \\
\hline $\mathrm{K}^{+}\left(\mathrm{cmol}_{\mathrm{c}} \mathrm{dm}^{-3}\right)$ & 0.33 & 0.73 & 10.15 & $<0.001$ & 0.76 & 0.60 \\
\hline $\mathrm{Ca}^{2+}\left(\mathrm{cmol}_{\mathrm{c}} \mathrm{dm}^{-3}\right)$ & 2.74 & 0.08 & 0.66 & 0.58 & 1.68 & 0.14 \\
\hline $\mathrm{Mg}^{2+}\left(\mathrm{cmol}_{\mathrm{c}} \mathrm{dm}^{-3}\right)$ & 1.12 & 0.34 & 0.46 & 0.71 & 1.01 & 0.42 \\
\hline CTC $\left(\mathrm{cmol}_{\mathrm{c}} \mathrm{dm}^{-3}\right)$ & 1.16 & 0.33 & 0.77 & 0.52 & 1.38 & 0.24 \\
\hline $\mathrm{pH}$ & 0.28 & 0.76 & 1.39 & 0.26 & 0.76 & 0.61 \\
\hline $\mathrm{m}(\%)$ & 0.70 & 0.50 & 0.16 & 0.93 & 1.75 & 0.12 \\
\hline $\mathrm{V}(\%)$ & 2.87 & 0.08 & 0.78 & 0.51 & 1.93 & 0.09 \\
\hline
\end{tabular}




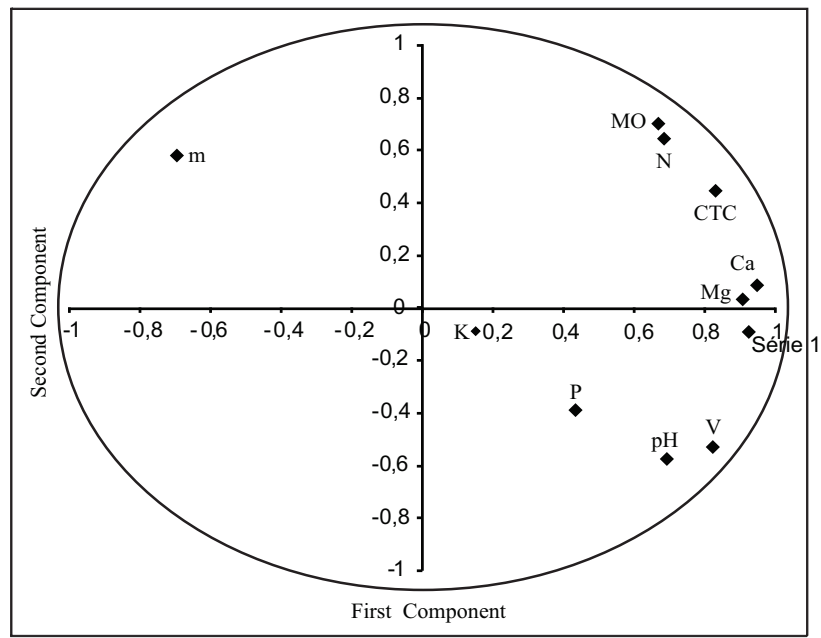

Figure 2. Eigenvectors of soil chemical variables, where: OM: organic matter; $\mathrm{m}$ : Al saturation; V: base saturation; N: nitrogen; CEC: cation exchange capacity; Ca: calcium; Mg: magnesium; P: phosphorus; pH: pH in water; K: potassium.

soil acidity is evidenced by the high correlation of the variable $\mathrm{m} \%$ of -0.70 (Figure 2 ); this variable represents the relationship between soil $\mathrm{Al}$ content and CEC. According to Lopes \& Guilherme (2004), the more acid a soil is, the higher is the content of exchangeable $\mathrm{Al}$ in absolute value, the lower the levels of $\mathrm{Ca}, \mathrm{Mg}$ and $\mathrm{K}$, the lower the sum of bases and the higher the percentage of $\mathrm{Al}$ saturation $(\mathrm{m} \%)$. The effect of soil liming was also seen in the high correlations of the variables $\mathrm{Ca}$ and $\mathrm{Mg}$ (Figure 2) which, in turn, resulted in the high correlations of $\mathrm{V}, \mathrm{CEC}$ and $\mathrm{pH}$ variables.

In the second component, correlations were highest between the variables $\mathrm{N}$ and $\mathrm{OM}$, and these in turn were most important for the formation of this component (Figure 2). The highest correlations for $\mathrm{OM}$ and $\mathrm{N}$ were explained by the fact that $\mathrm{OM}$ is a source of $\mathrm{N}$, when mineralized by microorganisms. According to Camargo et al. (2008), plant residues incorporated in the soil become a carbon and energy source for microorganisms and $\mathrm{N}$ is transformed from organic to inorganic forms that are available to plants. Also for the second component, the highest negative correlations were observed for $\mathrm{V} \%$ and $\mathrm{pH}$; i.e., with the increase in the $\mathrm{OM}$ content, there is a decrease of $\mathrm{V} \%$ and soil $\mathrm{pH}$. Meurer (2006) mentioned that this can be explained by the fact that in the process of mineralization and formation of humic substances $\mathrm{NO}_{3}-$ and $\mathrm{H}^{+}$ions are released, $\mathrm{NO}_{3}$ - anions are neutralized by cations ( $\mathrm{Ca}$ and $\mathrm{Mg}$, e.g.) from the solution, $\mathrm{V} \%$ is reduced, and $\mathrm{H}^{+}$remains in the solution, decreasing the $\mathrm{pH}$ value.

The grouping of strawberry fields (Figure 3 ) shows the distribution of fields based on the application of PCA for soil chemical variables in the $0-0.20 \mathrm{~m}$ soil layer.

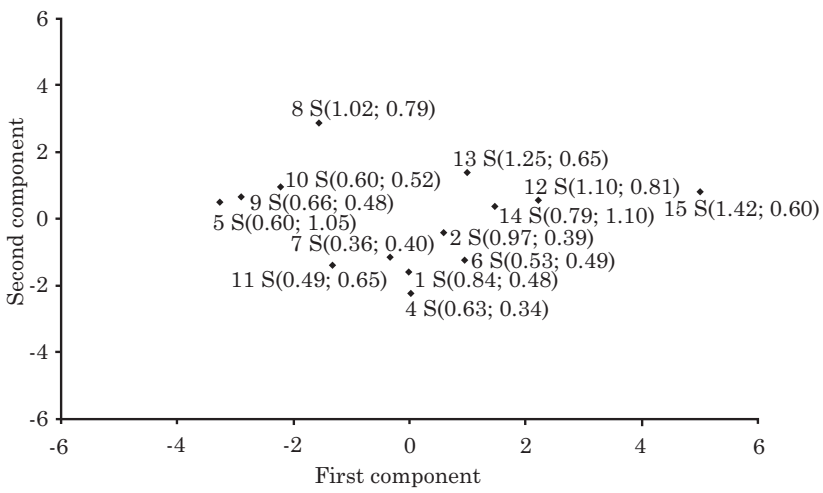

Figure 3. Grouping of strawberry fields based on the application of PCA for soil chemical variables in the 0-0.20 $\mathrm{m}$ layer. The $\mathrm{S}$ values in parentheses represent the standard deviation for the first and second components, respectively.

Based on the first component, the strawberry fields grouped on the negative axis were characterized by high $\mathrm{m} \%$ values (Figure 3 ). On the positive axis however, fields were grouped based on the values of $\mathrm{Ca}, \mathrm{Mg}, \mathrm{CEC}$, and $\mathrm{V} \%$, which are properties with better soil chemical characteristics. On six of the 14 fields under study, the $\mathrm{m} \%$ value was the most important for the soil chemical characterization. Moreover, based on the first component and according to the CQFSRS/SC (2004) classification, the soils of the fields 5, 8, 9 and 10 had a very low $\mathrm{pH}(\leq 5.0)$; very low base saturation ( $\mathrm{V} \%<45 \%)$ and high $\mathrm{Al}$ saturation $(m>20 \%)$, except for field 10 , with average Al saturation (between 10.1 and $20 \%$ ). These characteristics reinforced the need for an adequate liming and fertilization management on these fields. In a critical analysis of nutrition and fertilization of fruit trees, Kaminski (2011) reported that commercial strawberry fields are being heavily fertilized and that in spite of the high and very high nutrient levels, fertilization has been applied continuously.

The second component grouped the strawberry fields on the positive axis wherethe variables $\mathrm{OM}$ and $\mathrm{N}$ were important properties of their characterization (Figure 3). On the other hand, on the negative part of the axis were the fields with high $\mathrm{V} \%$ and $\mathrm{pH}$ values. In this component, the fields $12,13,14$ and 15 were noteworthy because despite being in the positive range, i.e., having higher $\mathrm{OM}$ values, the values of $\mathrm{V} \%$ and $\mathrm{pH}$ were also medium to high, which can be explained by the high CEC and Ca levels in the soil of these fields.

\section{CONCLUSIONS}

1. No spatial variation within the strawberry fields was observed for any of the soil fertility parameters studied. 
2. Temporal variation was only observed for potassium levels, which increased during the strawberry cycle.

3. According to the criteria of interpretation of analysis of soils in Rio Grande do Sul, phosphorus and potassium levels were always high or very high from the beginning of the strawberry cycle, whereas the $\mathrm{pH}$ values varied from very low to very high.

4. The principal component analysis allowed the grouping of strawberry fields based on variables related to soil acidity and organic matter.

\section{ACKNOWLEDGEMENTS}

The authors are indebted to the National Council for Scientific and Technological Development (CNPq) and the Brazilian Federal Agency for Support and Evaluation of Graduate Education (CAPES) for financial support and scholarships and wish to thank the farmers of the Association of Strawberry Producers of Turuçu-RS, who enabled this work. They also thank the staff of EMATER-Turuçu/RS for their help with this research.

\section{LITERATURE CITED}

ADHIKARI, P.; SHUKLA, M.K.; MEXAL, J.G.\& SHARMA, P.Assessment of the soil physical and chemical properties of desert soils irrigated with treated wastewater using principal component analysis. Soil Sci., 176:356-366, 2011.

ARAÚJO, V.F. Utilização de fertilizantes a base de xisto na produção e qualidade de morangos. Pelotas, Universidade Federal de Pelotas, 2011. 105p. (Dissertação de Mestrado)

BAMBERG, A.L.; CORNELIS, W.; TIMM, L.C.; GABRIELS, D.; PAULETTO, E.A. \& PINTO, L.F.S. Temporal changes of soil physical and hydraulic properties in strawberry fields. Soil Use Manage., 27:385-394, 2011.

CASTRO, R.L.; CASALI, V.W.D.; BARRELLA, T.P.; SANTOS, R.H.S. \& CRUZ, C.D. Produtividade de cultivares de morangueiro em sistema de cultivo orgânico. Hortic. Bras., 21:227-230, 2003.

CAMARGO, F.A.O.; SILVA, L.S.; GIANELLO, C.\& TEDESCO, M.J. Nitrogênio orgânico do solo. In: SANTOS, G.A.; SILVA, L.S.; CANELLAS, L.P.\& CAMARGO, F.A.O., eds. Fundamentos da matéria orgânica do solo: Ecossistemas tropicais e subtropicais. 2.ed. Porto Alegre, Metrópole, 2008. p.87-99.

CARVALHO JUNIOR, W.; SCHAEFER, C.E.G.R.; CHAGAS, C.S.\& FERNANDES FILHO, E.I. Análise multivariada de Argissolos da faixa atlântica brasileira. R. Bras. Ci. Solo, 32:2081-2090, 2008.
CARVALHO, S.P. Boletim do morango: Cultivo convencional, segurança alimentar, cultivo orgânico. Belo Horizonte, FAEMG, 2006. 160p.

COMISSÃO DE QUÍMICA E FERTILIDADE DO SOLOCQFSRS/SC. Manual de adubação e calagem para os estados do Rio Grande do Sul e Santa Catarina. 10.ed. Porto Alegre, Sociedade Brasileira de Ciência do Solo Núcleo regional Sul, 2004. 394p.

DOMÍNGUEZ, A.; MARTINEZ, E.; TRIGO, A.; ALONSO, D.; GARCIA, R.; SANCHEZ, R.; GHORBEL, R. \& TOMAS, J. Seasonal changes in leaf mineral content may affect foliar diagnostic in strawberry. Proceedings of the $6^{\text {th }}$ International Strawberry Symposium.ActaHortic., 842:147-150, 2009.

ESTRELA, C.C. Variabilidade espacial e temporal da qualidade da água de irrigação no sistema de produção de morango em propriedades familiares no município de Turuçu-RS. Pelotas, Universidade Federal de Pelotas, 2008. 114p. (Dissertação de Mestrado)

FOOD AND AGRICULTURE ORGANIZATION OF THE UNITED NATIONS - FAO. FAOSTAT: Agricultural Production/strawberry. Available at: <http:// www.faostat.fao.org>. Accessed Aug. 21, 2011.

FERREIRA, D.F. Estatística multivariada. Lavras, Universidade Federal de Lavras, 2008. 662p.

GUEDES, M.C.; ANDRADE, C.A.; POGGIANI, F. \& MATTIAZZO, M.E. Propriedades químicas do solo e nutrição do eucalipto em função da aplicação de lodo de esgoto.R. Bras. Ci. Solo, 30:267-280, 2006.

KAMINSKI, J. Recomendação de fertilizantes para fruteiras: Desafio ou apenas um recomeço? B. Inf. SBCS, 1:2223, 2011.

KAMINSKI, J.; SILVA, L.S.; CERETTA, C.A. \& SANTOS, D.R. Acidez e calagem em solos do Sul do Brasil: Aspectos históricos e perspectivas futuras. In: CERETTA, C.A.; SILVA, L.S. \& REICHERT, J.M., eds. Tópicos em ciência do solo. Viçosa, MG, Sociedade Brasileira de Ciência do Solo, 2007. v.5. p.307-332.

LOPES, A.S. \& GUILHERME, L.R.G.Interpretação de análise de solo - Conceitos e aplicações. 3.ed. São Paulo, Associação Nacional para Difusão de Adubos - ANDA, 2004. 50p. (Boletim Técnico, 2)

MANDAL, U.K.; WARRINGTON, D.N.; BHARDWAJ, A.K.; BAR-TAL, A.; KAUTSKY, L.; MINZ, D. \& LEVY, G.J. Evaluating impact of irrigation water quality on a calcareous clay soil using principal component analysis. Geoderma, 144:189-197, 2008.

MARSCHNER, H.Mineral nutrition of higher plants. San Diego, Academic Press, 1995. 889p.

MEURER, E.J. Fundamentos de química do solo. 3.ed. Porto Alegre, Evangraf, 2006. 285p. 
NYIRANEZA, J.; N’DAYEGAMYNE, A.; CHANTIGNY, M.H. \& LAVERDIÈRE, M.R. Variations in corn yield and nitrogen uptake in relation to soil properties and nitrogen availability indices. Soil Sci. Soc. Am. J., 73:317-327, 2009.

PORTAL DO AGRONEGÓCIO. Available at: <http:// www.portaldoagronegócio.com.br> Accessed Oct. 18, 2011.

SANTOS, A.M.; MEDEIROS, A.R.M. \& WREGE, M.S. Sistema de produção de morango. Pelotas, Embrapa Clima Temperado, 2005. Available at: <http:// sistemadeprodução.cnptia.embrapa.br/Fonteshtml/ Morango/Sistemaproduçãomorango/cap.10.html> Accessed Jan. 26, 2011.

STATISTICAL ANALYSIS SYSTEM - SAS.User's Guide. 5.ed. Cary, 1985.

SOIL SURVEY STAFF. Keys to soil taxonomy. 10.ed. Washington,USDA - Natural Resources Conservation Service, 2006.

TAGLIANI, C.R.A. A mineração na porção média da Planície Costeira do Rio Grande do Sul: estratégia para a gestão sob um enfoque de Gerenciamento Costeiro Integrado. Porto Alegre, Universidade Federal do Rio Grande do Sul, 2002. 252p. (Tese de Doutorado)
TAGLIAVINI, M.; BALDI, E.; LUCCHI, P.; ANTONELLI, M.; SORRENTI, G.; BARUZZI, G. \& FAEDI, W. Dynamics of nutrients uptake by strawberry plants (Fragaria $x$ ananassa Dutch.) grown in soil and soilless culture. Eur. J. Agron., 23:15-25, 2005.

TEDESCO, M.J.; GIANELLO, C.; BISSANI, C.A.; BOHNEN, H. \& VOLKWEISS, S.J. Análise de solo, plantas e outros materiais. 2.ed. Porto Alegre, Universidade Federal do Rio Grande do Sul, 1995. 174p.

VALLADARES, G.S.; GOMES, E.G.; MELLO, J.C.C.B.S.; PEREIRA, M.G.; ANJOS, H.C.; EBELING, A.G. \& BENITES, V.M. Análise dos componentes principais e métodos multicritério ordinais no estudo de Organossolos e solos afins. R. Bras. Ci. Solo, 32:285-296, 2008.

VISCONTI, F.; PAZ, J.M. \& RUBIO, J.L. Principal component analysis of chemical properties of soil saturation extracts from an irrigated Mediterranean area: Implications for calcite equilibrium in soil solutions. Geoderma, 151:407416, 2009.

WILDING, L.P. \& DREES, L.R.Spatial variability and pedology. In: WILDING, L.P.; SMECK, N.E.\& HALL, G.F., eds. Pedogenesis and soil taxonomy: Concepts and interactions. Amsterdam, Elsevier Publishing, 1983. p.83116. 